\title{
Phenotypic and genotypic characterization of $m c r-1$-positive multidrug-resistant Escherichia coli ST93, ST117, ST156, ST10, and ST744 isolated from poultry in Poland
}

\author{
Katarzyna Ćwiek ${ }^{1} \cdot$ Anna Woźniak-Biel ${ }^{1}\left[\right.$ ? Magdalena Karwańska ${ }^{1} \cdot$ Magdalena Siedlecka $^{1} \cdot$ Christine Lammens $^{2}$. \\ Ana Rita Rebelo ${ }^{3} \cdot$ Rene S. Hendriksen ${ }^{3} \cdot$ Maciej Kuczkowski ${ }^{1} \cdot$ Monika Chmielewska-Władyka ${ }^{1} \cdot$ Alina Wieliczko $^{1}$
}

Received: 22 December 2020 / Accepted: 29 May 2021 / Published online: 10 June 2021

(c) The Author(s) 2021

\begin{abstract}
Background A plasmid-mediated mechanism of bacterial resistance to polymyxin is a serious threat to public health worldwide. The present study aimed to determine the occurrence of plasmid-mediated colistin resistance genes and to conduct the molecular characterization of $m c r$-positive Escherichia coli strains isolated from Polish poultry.

Methods In this study, 318 E. coli strains were characterized by the prevalence of $m c r 1-m c r 5$ genes, antimicrobial susceptibility testing by minimal inhibitory concentration method, the presence of antimicrobial resistance genes was screened by PCR, and the biofilm formation ability was tested using the crystal violet staining method. Genetic relatedness of $m c r-$ 1 -positive $E$. coli strains was evaluated by multilocus sequence typing method.

Results Among the 318 E. coli isolates, 17 (5.35\%) harbored the $m c r-1$ gene. High antimicrobial resistance rates were observed for ampicillin (100\%), tetracycline (88.24\%), and chloramphenicol (82.35\%). All mcr-1-positive E. coli strains were multidrug-resistant, and as many as $88.24 \%$ of the isolates contained the bla $a_{\mathrm{TEM}}$ gene, tetracycline (tetA and tetB), and sulfonamide (sull, sul2, and sul3) resistance genes. Additionally, $41.18 \%$ of multidrug-resistant, $m c r-1$-positive $E$. coli isolates were moderate biofilm producers, while the rest of the strains showed weak biofilm production. Nine different sequence types were identified, and the dominant ST was ST93 (29.41\%), followed by ST117 (17.65\%), ST156 (11.76\%), ST 8979 (11.76\%), ST744 (5.88\%), and ST10 (5.88\%). Moreover, the new ST was identified in this study.

Conclusions Our results showed a low occurrence of $m c r$ - 1 -positive E. coli strains isolated from Polish poultry; however, all the isolated strains were resistant to multiple antimicrobial agents and were able to form biofilms at low or medium level.
\end{abstract}

Keywords Escherichia coli $\cdot$ Mcr- $1 \cdot$ Multidrug resistance $\cdot$ MLST $\cdot$ Biofilm $\cdot$ Sequence type

Anna Woźniak-Biel

anna.wozniak-biel@upwr.edu.pl

1 The Faculty of Veterinary Medicine, Department of Epizootiology and Clinic of Birds and Exotic Animals, Wrocław University of Environmental and Life Sciences, Pl. Grunwaldzki 45, 50-366 Wrocław, Poland

2 University of Antwerp, Campus Drie Eiken Universiteitsplein 1, D.S.624, 2610 Wilrijk, Belgium

3 WHO Collaborating Center for Antimicrobial Resistance in Foodborne Pathogens and European Union Reference Laboratory for Antimicrobial Resistance, National Food Institute, Technical University of Denmark, Kemitorvet Building 204, 2800 Lyngby, Denmark

\section{Introduction}

Antimicrobial resistance (AMR) has emerged as one of the most important global threats to human health in the last few decades. The increasing resistance of Gram-negative bacteria isolated from poultry is receiving high attention, especially in terms of public health protection, but also in the ability to successfully treat bacterial infections in birds. Resistant bacteria can be transmitted from animals to humans via direct contact between animals and humans, or through the food chain and the environment [1]. A crucial issue seems to be the more frequent isolation of Gramnegative strains resistant to colistin from slaughter animals, e.g., poultry, pigs, and calves [2-4].

In poultry production, colistin (polymyxin E) has been widely administered for the treatment and metaphylaxis of 
avian colibacillosis, gastroenteritis, and diarrhea to reduce high incidence and mortalities. Such overuse and/or misuse of antibiotics contribute to the development and spread of AMR among poultry strains and flocks, leading to the emergence of multidrug-resistant (MDR) pathogens [5].

The mechanism of action of colistin is the ability of the drug to bind to the surface structures of the bacterial cell membrane (phospholipids and lipopolysaccharides (LPS)), which increases its permeability and weakens the osmotic integrity of the cytoplasmic membrane, while resistance to colistin is an effect of the inefficient binding of polymyxins to the lipid A moiety of LPS due to the 4'-phosphoethanolamine (PEA) modification of lipid A on the LPS [6]. Colistin resistance may be encoded chromosomally or by the $\mathrm{mcr}$ genes located on mobile genetic elements in plasmid DNA. Chromosomally mediated resistance to colistin is caused by single nucleotide polymorphism in $p m r A B$, phoPQ, $m g r B$, and/or $p m r D$ genes, resulting in modification of lipid A [7]. In 2015, Liu et al. [8] reported the first case of a plasmid-mediated colistin resistance mechanism, designated mcr-1, in E. coli and Klebsiella pneumoniae. Since then, an increasing number of $m c r$ genes have been identified. At present, 10 different $m c r$ genes and their variants have been described, and these discoveries indicate a rapid evolution of plasmid-mediated colistin resistance gene family [3,9-15]. The $m c r-1, m c r-2$, and $m c r-3$ genes were originally characterized on plasmids in Enterobacteriaceae, but have recently been identified on chromosomes in Moraxella spp. and Aeromonas veronii [16, 17]. Additionally, $m c r-4, m c r-5, m c r-6, m c r-7$, and $m c r-8$ genes, compared to those listed above, have been described relatively recently. In 2019, the novel $m c r-9$ homolog was detected in the clinical isolate of Salmonella Typhimurium in the USA [18]. The first case of identification of the latest variant $\mathrm{mcr}$ - 10 in an Enterobacter roggenkamp strain was reported in 2020 [19]. Currently, $m c r$ genes have been globally distributed, and an in silico analysis showed their presence on plasmids and their high prevalence among Enterobacteriaceae strains isolated from humans, animals, food, and environment [15]. Moreover, this resistance could be easily transferred to other bacterial cells during cell division or horizontal gene transfer (e.g., conjugation or transduction) [20,21].

It is worth noting that the transferable plasmid-mediated genes that could rapidly spread between bacterial species and hosts, and the possible transmission of resistance genes due to cross-contamination between food-production chains, animals, and humans have raised worldwide concern in recent years $[6,8,22]$.

In human medicine, polymyxins are used only for the emergence of MDR bacteria, which are responsible for severe infections and deaths, as a last resort antimicrobial agent against these "super bacteria." The spread of diverse antimicrobial resistance genes in Enterobacteriaceae, e.g., colistin and quinolone resistance genes, is well known among the bacteria within this family [23, 24].

Currently, with the increase in resistance of bacteria to commonly used antimicrobial agents, polymyxins are also used as the last resort therapy for biofilm-related infections. Biofilm is a multicellular structure, which is defined as a community of cooperating bacteria that adhere to biological or nonbiological surfaces contained in the extracellular polymeric matrix [25]. Bacteria embedded in the inner layers of the biofilm may show less susceptibility to antibiotics due to increased horizontal gene transmission, modification of the antibiotic target or cell permeability, and the use of efflux pumps or the expression of hydrolyzing enzymes. Colistin can act against metabolically inactive bacterial cells in the inner layers of the biofilm. Because of this property, colistin is the subject of research in which combined antibiotic therapy is recommended as a treatment for biofilm-related infections caused by Gram-negative bacteria [26, 27].

In the last few years, several reports have been published on the detection and characterization of colistin-resistant $E$. coli strains isolated from slaughter animals [4, 8, 28-31]. Studies on colistin resistance and the prevalence of resistance-associated genes among bacterial strains from various sources have been conducted worldwide. In Poland, studies on colistin-resistant $E$. coli strains isolated from slaughter and wild animals were conducted by Wasyl et al. [32, 33], Zając et al. [34], and Majewski et al. [35]. Those studies were mainly focused on the antimicrobial resistance of $E$. coli strains, the presence of $m c r$ genes, and molecular identification and characterization of resistance mechanisms. However, there is still scarce research on the relationship between AMR, genotypic characterization (AMR genes, multilocus sequence typing - MLST), and the ability of biofilm formation in $m c r-1$-positive E. coli strains isolated from poultry in Poland.

The present study aimed to assess the prevalence of the $m c r$ genes among $E$. coli strains isolated from different types of poultry (broilers, laying hens, turkeys, geese, and ducks), to determine the antimicrobial susceptibility phenotypes of $m c r$-positive strains, and to evaluate the association of observed phenotypes with the presence of AMR genes, MLST sequence types, and the ability of biofilm production by these strains.

\section{Material and methods}

\section{Isolate collection}

A total of 318 E. coli isolates were obtained from the AGROVET Veterinary Laboratory in Wrocław, Poland. The strains were collected during 2016-2020 from different types of poultry: broilers $(n=161)$, turkeys $(n=72)$, breeder broilers 
$(n=37)$, laying hens $(n=20)$, ducks $(n=14)$, and geese $(n=14)$. Strains were isolated from organs with lesions or from cloacal swabs and identified using standard microbial and chromogenic media for coliform bacteria, especially those for selective isolation of $E$. coli.

\section{DNA isolation}

Total DNA of all 318 E. coli strains was isolated from 18to 20-h culture of the strains in LB medium (BIOCORP, Warszawa, Poland) incubated at $37^{\circ} \mathrm{C}$. For DNA extraction, the commercial Genomic Mini ${ }^{\circledR}$ kit (A\&A Biotechnology, Gdynia, Poland) was used and the procedure was performed according to the manufacturer's protocol. The purity and concentration of the obtained DNA were assessed using a spectrophotometer, and the amount of DNA was estimated to be approximately $30 \mathrm{ng} / \mu \mathrm{l}$. As good quality DNA, the A260/ A280 ratio of 1.7-2.0 and A260/A230 greater than 1.5 were taken [36]. The obtained DNA of strains was protected and stored at $-20{ }^{\circ} \mathrm{C}$ until further tests.

\section{PCR-based screening of colistin resistance genes}

Multiplex PCR was used to amplify part of the five colistin resistance genes $m c r-1, m c r-2, m c r-3, m c r-4$, and $m c r-5$ in all 318 E. coli strains according to published protocol [37] with minor modification. Each PCR reaction was performed in $25 \mu \mathrm{l}$ total volume consisting of $2.5 \mu \mathrm{l} 10 \times$ DreamTaq Green Buffer (Thermo Fisher Scientific, Waltham, USA), each primer at $0.2 \mu \mathrm{M}$ final concentration (Genomed, Warszawa, Poland), $0.2 \mathrm{mM}$ nucleotide mix (Thermo Fisher Scientific), $1 \mathrm{U}$ of DreamTaq Green Polymerase (Thermo Fisher Scientific), and $1 \mu$ DNA template. The thermal profile included initial denaturation at $95{ }^{\circ} \mathrm{C}$ for $10 \mathrm{~min}$, followed by 30 cycles of denaturation at $95^{\circ} \mathrm{C}$ for $30 \mathrm{~s}$, annealing at $63{ }^{\circ} \mathrm{C}$ for $90 \mathrm{~s}$, elongation at $72{ }^{\circ} \mathrm{C}$ for $60 \mathrm{~s}$, and final elongation at $72{ }^{\circ} \mathrm{C}$ for $10 \mathrm{~min}$. The PCR products were run on $1.5 \%$ agarose gel with Midori Green DNA Stain (Nippon Genetics Europe GmbH, Dueren, Germany) at $100 \mathrm{~V}$. PCR products with the expected base pair size $(320,715,929,1116$, and $1644 \mathrm{bp}$, respectively) were subsequently sequenced and then analyzed using BioEdit (v. 7.2.5) software and GenBank database to confirm the test results.

As positive controls for $m c r$ genes ( $m c r-1, m c r-2, m c r-3$, $m c r-4, m c r-5)$ detection, the following strains were used in this study: E. coli KP81 and E. coli KP37 for the detection of $m c r-1$ and $m c r-2$ genes, respectively. Strains were given by Christine Lammens from the University of Antwerp in Belgium. Moreover, E. coli SQ352, E. coli DH5 $\alpha$, and Salmonella paratyphi B-SA01718 were used as positive controls for $m c r-3, m c r-4$, and $m c r-5$ gene detection, respectively. These strains were obtained from the European Union
Reference Laboratory for Antimicrobial Resistance at the National Food Institute, Technical University in Denmark.

\section{Antimicrobial susceptibility test}

The examination of antimicrobial susceptibility to selected antimicrobial agents was performed by determination of minimal inhibitory concentration (MIC) using the commercial system MIC Sensititre EU Surveillance Salmonella/E. coli EUVSEC Plate (Thermo Fisher Scientific, WalthamAZI, USA) according to the manufacturer's instructions. Resistance breakpoints to fourteen antimicrobial agents, namely gentamicin (GEN), ampicillin (AMP), cefotaxime (CTX), ceftazidime (CAZ), meropenem (MEM), nalidixic acid (NAL), ciprofloxacin (CIP), chloramphenicol (CHL), azithromycin (AZM), colistin (CST), tetracycline (TET), tigecycline (TGC), sulfamethoxazole (SMX), and trimethoprim (TMP), were determined for $m c r$-1-positive strains. The tested $E$. coli strains were classified as susceptible (S) or resistant $(\mathrm{R})$ based on EUCAST guidelines, version 10.0, 2020 [38]. In the case of absence of limit values for selected antimicrobials, the guidelines of the Clinical Laboratory Standards Institute (CLSI) were used to analyze the results [39]. The reference strain of E. coli ATCC 25,922 was used as test control. In addition, the investigated isolates were categorized as multidrug resistant (MDR), when they were simultaneously resistant to at least three antimicrobial agents from different classes of antimicrobial agents [30].

\section{Detection of antimicrobial resistance genes}

PCR amplification of the genes related to resistance to betalactams (bla $a_{\mathrm{CTX}-\mathrm{M}}, b l a_{\mathrm{SHV}}$, and $\left.b l a_{\mathrm{TEM}}\right)$, quinolones (qnrA, $q n r B, q n r C, q n r D, q n r S, q e p A$, and $\left.a a c\left(6^{\prime}\right)-I b-c r\right)$, phenicols (cat1, cat2, and cat3), tetracyclines (tet $A$, tet $B$, tet $C$, and tetD), and sulfonamides (sull, sul2, and sul3) was performed for the $E$. coli isolates carrying the $m c r-1$ gene [30, $31,40]$. These genes were chosen as a molecular resistance mechanism of $E$. coli to the selected antimicrobials used for antimicrobial susceptibility tests in this study. Sequenced PCR products of resistance genes, collected during previous studies, were used as positive controls in this study [41].

\section{Biofilm formation by mcr-1-positive E. coli strains}

Biofilm formation was tested in 96-well flat polystyrene microtiter plates (Corning Inc., New York, USA), based on a modified protocol previously described [26, 42]. The mcr-1-positive $E$. coli strains were cultured overnight in LB medium, adjusted to a density of $0.5 \mathrm{McF}$ arland units, and then diluted in a proportion of 1:9 with fresh LB medium. A volume of 200- $\mu$ l aliquots of each dilution was then dispensed into a microtiter plate well, and each 
bacterial suspension was inoculated in 6 wells. Negative controls for the test were uninoculated LB medium. To compare biofilm formation, the results of $m c r$ - 1 -positive E. coli isolates, E. coli ATCC 25,922, and three collected E. coli strains without $m c r-1$ were used. The microtiter plate was incubated for $24 \mathrm{~h}$ in aerobic conditions at $37{ }^{\circ} \mathrm{C}$ without shaking.

After incubation, the supernatant was discarded, and the microtiter plate was washed three times gently with $250 \mu \mathrm{l}$ of phosphate buffer solution (PBS). Microplates were then stained with $200 \mu \mathrm{l}$ of $0.1 \%$ crystal violet for $15 \mathrm{~min}$, washed thrice with PBS, and dried for $30 \mathrm{~min}$. Adherent cells were solubilized with $200 \mu \mathrm{l}$ of $95 \%$ ethanol. $\mathrm{OD}_{590}$ (optical density) was measured using an automated microplate reader Spark (Tecan Group Ltd., Männedorf, Switzerland). Based on the OD produced by bacterial biofilms and established cut-off value (ODc), the strains were classified into the following categories: no biofilm former $-\mathrm{OD} \leq \mathrm{ODc}$, weak biofilm former - ODc $<\mathrm{OD} \leq 2 \mathrm{ODc}$, moderate biofilm former $-2 \mathrm{ODc}<\mathrm{OD} \leq 4 \mathrm{ODc}$, or strong biofilm former 4 ODc $<$ OD $[25,43]$.

\section{MLST of the mcr-1-positive strains}

The $m c r$ - 1 -positive $E$. coli isolates were analyzed using the MLST method to determine the sequence types (STs). Depending on the alleles of seven basic metabolism genes (housekeeping genes), namely $a d k$, fumC, gyrB, icd, $m d h$, purA, and recA, the Achtman MLST method was performed using the EnteroBase (v.1.1.2) database (http://enterobase. warwick.ac.uk), and the protocol described by Wirth et al. [44]. Sequences of seven housekeeping genes were concatenated for each isolate using BioEdit (v. 7.2.5), and then the phylogenetic tree was reconstructed by the neighbor-joining method with 1000 bootstrap trials, and Kimura's correction using MEGA 6.0 software [45-47].

\section{Results}

\section{PCR-based screening of colistin resistance genes}

Among all the tested E. coli strains $(\mathrm{n}=318), 17$ isolates $(5.35 \%)$ were $m c r-1$ positive, whose presence was confirmed by the $100 \%$ of nucleotide identity of the amplicons when they were sequenced (https://blast.ncbi.nlm.nih.gov/Blast. cgi). The $m c r-2, m c r-3, m c r-4$, and $m c r-5$ genes were not detected in any of the collected $E$. coli strains. Most of the $m c r$ - 1 harboring $E$. coli strains were isolated from turkeys ( 9 ; $52.94 \%$ ), followed by seven strains $(41.18 \%)$ from broilers and one strain $(5.88 \%)$ from goose.

\section{Antimicrobial susceptibility}

Antimicrobial susceptibility of the $E$. coli strains carrying the detected $m c r-1$ gene is shown in Table 2 Occurrence of resistance genes to antimicrobial agents, resistance profiles, biofilm formation, and sequence types (STs) in mcr-1-positive Escherichia coli strains $(n=17)$ [Display Image Removed] White square - lack of resistance gene; black square - presence of resistance gene.GEN, gentamicin; AMP, ampicillin; CTX, cefotaxime; CAZ, ceftazidime; MEM, meropenem; NAL, nalidixic acid; CIP, ciprofloxacin; CHL, chloramphenicol, AZM, azithromycin; CST, colistin; TET, tetracycline; TGC, tigecycline; SMX, sulfamethoxazole; TMP, trimethoprim.Biofilm formation: +++- strong biofilm former, ++- moderate biofilm former, +- weak biofilm former. Table 1 and in Fig. 1. All $m c r-1$-positive $E$. coli strains $(\mathrm{n}=17)$ were susceptible (100\%) to meropenem (MIC value $0.03 \mu \mathrm{g} /$ $\mathrm{ml})$. In addition, most strains were susceptible to azithromycin $(94.12 \%$, MIC range of $2-8 \mu \mathrm{g} / \mathrm{ml})$, ceftazidime (82.35\%, MIC range of $0.5-1 \mu \mathrm{g} / \mathrm{ml})$, cefotaxime $(82.35 \%$, MIC range of $0.25-1 \mu \mathrm{g} / \mathrm{ml})$, and tigecycline $(76.47 \%$, MIC range of $0.25-0.5 \mu \mathrm{g} / \mathrm{ml})$. Similarly, the percentage of strains susceptible to gentamicin was relatively high (76.47\%; MIC range of $0.5-1 \mu \mathrm{g} / \mathrm{ml}$ ).

On the other hand, all strains $(100 \%)$ were resistant to ampicillin (MIC $>64 \mu \mathrm{g} / \mathrm{ml}$ ). The occurrence of resistant isolates to tetracycline (88.24\%), chloramphenicol (82.35\%) nalidixic acid (76.47\%), and ciprofloxacin (64.71\%) was also high. MIC values for tetracycline-resistant strains $(n=15)$ were in the range of $64 \mu \mathrm{g} / \mathrm{ml}$ ( 2 strains) and $>64 \mu \mathrm{g} / \mathrm{ml}$ (13 strains). The ranges of MIC values for chloramphenicolresistant strains were varied and were as follows: $32 \mu \mathrm{g} / \mathrm{ml}$ $(\mathrm{n}=3), 64 \mu \mathrm{g} / \mathrm{ml}(\mathrm{n}=3), 128 \mu \mathrm{g} / \mathrm{ml}(\mathrm{n}=8)$, and $>128 \mu \mathrm{g} /$ $\mathrm{ml}(\mathrm{n}=2)$. Among the $E$. coli strains resistant to nalidixic acid, the MIC value for all strains was $>128 \mu \mathrm{g} / \mathrm{ml}$, while the MIC value for ciprofloxacin ranged between 4 and $\geq 8 \mu \mathrm{g} / \mathrm{ml}$.

It is worth emphasizing that among the $17 \mathrm{mcr}$ - 1 -positive $E$. coli isolates, only nine strains $(52.94 \%)$ were resistant to colistin; among these strains, the MIC value was $8 \mu \mathrm{g} /$ $\mathrm{ml}$ for eight strains $(88.89 \%)$. In all E. coli strains resistant to sulfamethoxazole $(15 ; 88.24 \%)$, the MIC value exceeded $1024 \mu \mathrm{g} / \mathrm{ml}$, while in strains resistant to trimethoprim (14; $82.35 \%$ ), the MIC value ranged from 8 to $\geq 32 \mu \mathrm{g} / \mathrm{ml}$.

Interestingly, among the $17 \mathrm{mcr}-1$-positive $E$. coli strains isolated from different poultry types, the resistance to the 13 tested antimicrobial agents was similar. An exception was the resistance to colistin, wherein six of strains were derived from broilers (35.29\%), two from turkeys (11.76\%), and one E. coli isolate (5.88\%) from goose.

On the basis of the interpretation of MIC breakpoint values, according to EUCAST recommendations [38], 15 resistance profiles of the isolated $E$. coli strains were 
Table 1 Minimal inhibitory concentration (MIC) $(\mu \mathrm{g} / \mathrm{ml})$ of $m c r$-1-positive Escherichia coli strains $(\mathrm{n}=17)$

\begin{tabular}{|c|c|c|c|c|c|c|c|c|c|c|c|c|c|c|c|}
\hline \multirow[t]{2}{*}{ Origin } & \multirow[t]{2}{*}{ Strain } & \multicolumn{14}{|c|}{ MIC value $(\mu \mathrm{g} / \mathrm{ml})$} \\
\hline & & GEN & AMP & CTX & CAZ & MEM & NAL & CIP & $\mathrm{CHL}$ & $\mathrm{AZM}$ & CST & TET & TGC & SMX & TMP \\
\hline \multirow[t]{9}{*}{ Turkeys } & $\mathrm{RF} 1 / 17$ & 0.5 & $>64$ & 4 & 4 & $<0.03$ & 4 & 8 & 8 & 8 & 1 & $>64$ & 0.5 & 8 & 8 \\
\hline & RF2/17 & 1 & $>64$ & 4 & 4 & $<0.03$ & 4 & 0.015 & 8 & 8 & 1 & $>64$ & 0.5 & $>1024$ & 32 \\
\hline & $\mathrm{RP} 1 / 17$ & 1 & $>64$ & 0.25 & 0.5 & $<0.03$ & $>128$ & $>8$ & 32 & 2 & 1 & $>64$ & 0.25 & $>1024$ & $>32$ \\
\hline & $\mathrm{RP} 2 / 17$ & 1 & $>64$ & 0.25 & 0.5 & $<0.03$ & $>128$ & $>8$ & 32 & 2 & 1 & $>64$ & 0.25 & $>1024$ & $>32$ \\
\hline & $\mathrm{RP} 3 / 17$ & 0.5 & $>64$ & 0.25 & 0.5 & $<0.03$ & $>128$ & 0.25 & $>128$ & 8 & 1 & $>64$ & 0.5 & 8 & 0.25 \\
\hline & $\mathrm{AE} 02 / 18$ & 1 & $>64$ & $<0.25$ & $<0.5$ & $<0.03$ & $>128$ & 8 & $<8$ & 4 & 8 & $>64$ & 1 & $>1024$ & $<0.25$ \\
\hline & AE21/18 & $>32$ & $>64$ & $<0.25$ & $<0.5$ & $<0.03$ & $<4$ & 0.03 & 64 & $<2$ & 2 & 4 & 2 & $>1024$ & 1 \\
\hline & $\mathrm{AE} 178 / 20$ & $<0.5$ & $>64$ & $<0.25$ & $<0.5$ & $<0.03$ & $>128$ & 8 & 128 & 16 & $<1$ & $>64$ & $<0.25$ & $>1024$ & $>32$ \\
\hline & AE342/20 & 32 & $>64$ & $<0.25$ & $<0.5$ & $<0.03$ & $<4$ & $<0.015$ & 32 & $<2$ & 4 & 64 & $<0.25$ & $>1024$ & $>32$ \\
\hline \multirow[t]{7}{*}{ Broilers } & RW1/17 & 0.5 & $>64$ & 0.5 & 0.5 & $<0.03$ & $>128$ & 0.25 & 64 & 2 & 8 & 2 & 0.5 & $>1024$ & $>32$ \\
\hline & RW2/17 & $>32$ & $>64$ & 1 & 0.5 & $<0.03$ & $>128$ & $>8$ & 128 & 8 & 8 & $>64$ & 0.5 & $>1024$ & $>32$ \\
\hline & RW3/17 & 8 & $>64$ & $>4$ & 4 & $<0.03$ & $>128$ & $>8$ & 128 & $<2$ & 2 & $>64$ & $<0.25$ & $>1024$ & $>32$ \\
\hline & AE64/18 & $>32$ & $>64$ & $<0.25$ & 1 & $<0.03$ & $>128$ & $>8$ & $>128$ & 8 & 8 & $>64$ & 2 & $>1024$ & $>32$ \\
\hline & AE71/18 & 1 & $>64$ & $<0.25$ & $<0.5$ & $<0.03$ & $>128$ & 0.25 & 64 & 4 & 8 & 64 & $<0.25$ & $>1024$ & $>32$ \\
\hline & AE256/20 & $<0.5$ & $>64$ & $<0.25$ & $<0.5$ & $<0.03$ & $>128$ & 4 & 128 & $<2$ & 8 & $>64$ & $<0.25$ & $>1024$ & $>32$ \\
\hline & AE257/20 & $<0.5$ & $>64$ & $<0.25$ & $<0.5$ & $<0.03$ & $>128$ & 4 & 128 & $<2$ & 8 & $>64$ & $<0.25$ & $>1024$ & $>32$ \\
\hline Geese & AE05/18 & 1 & $>64$ & $<0.25$ & $<0.5$ & $<0.03$ & $>128$ & 8 & 128 & 4 & 8 & $>64$ & 1 & $>1024$ & $>32$ \\
\hline
\end{tabular}

Bold — resistance to an antimicrobial agent; italics — susceptible to an antimicrobial agent.

$G E N$, gentamicin; $A M P$, ampicillin; $C T X$, cefotaxime; $C A Z$, ceftazidime; $M E M$, meropenem; $N A L$, nalidixic acid; $C I P$, ciprofloxacin; $C H L$, chloramphenicol; $A Z M$, azithromycin; $C S T$, colistin; TET, tetracycline; $T G C$, tigecycline; $S M X$, sulfamethoxazole; $T M P$, trimethoprim.

described. All the investigated isolates were MDR. The 15 resistance profiles obtained in this study are presented in Table 2.

The most common resistance profile consisted of six classes of antimicrobial agents: $\mathrm{AMP}+\mathrm{NAL}+\mathrm{CIP}+\mathrm{CHL}+$ $\mathrm{CST}+\mathrm{TET}+\mathrm{SMX}+\mathrm{TMP}$ and was observed in two strains of $E$. coli (AE256/20 and AE257/20) isolated from the internal organs of broilers. Another two E. coli strains isolated from the organs of turkey (RP1/17 and RP2/17) had a resistance profile of five classes of antimicrobial agents: AMP $+\mathrm{N}$ $\mathrm{AL}+\mathrm{CIP}+\mathrm{CHL}+\mathrm{TET}+\mathrm{SMX}+\mathrm{TMP}$; their resistance profiles (even for 7 classes of antimicrobial agents) were noted in single strains of $E$. coli isolated from different sources and places (turkeys, broilers, and geese; organs and cloacal swabs).

It is worth noting that among the $m c r-1$-positive $E$. coli strains isolated from chicken broilers, two strains (11.76\%) exhibited resistance profile to as many as 7 classes of antimicrobial agents, four strains $(23.53 \%)$ to 6 classes, and one strain $(5.88 \%)$ to 5 classes of antimicrobial agents. In contrast, among isolates from turkeys, most strains showed a resistance profile to 5 classes of antimicrobial agents ( 5 strains, $29.41 \%$ ). The remaining $E$. coli isolates showed resistance profiles to 6 classes ( 2 strains; $11.76 \%$ ) and 4 classes ( 2 strains, $11.76 \%$ ) of antimicrobial agents. The isolate from the goose was resistant to antimicrobial agents from 6 classes.

\section{Occurrence of resistance genes and biofilm formation}

The occurrence of the selected resistance genes among the mcr-1-positive E. coli strains isolated from poultry is shown in Table 2. The results showed the frequent presence of one of the beta-lactam resistance genes $\left(b l a_{\mathrm{TEM}}\right)(88.24 \%)$ in the isolated $E$. coli strains, with the simultaneous absence of the other two resistance genes to this class of antibiotics $\left(b l a_{\mathrm{SHV}}\right.$ and $\left.b l a_{\mathrm{CTX}-\mathrm{M}}\right)$. The percentage of strains that harbored the sulfonamide resistance genes was as follows: sull $-70.59 \%$, sul $-70.59 \%$, and sul3 $-52.94 \%$. All the three genes were detected in $29.41 \%$ of $m c r-1$-positive $E$. coli strains. In addition, $70.59 \%$ of $E$. coli isolates showed the presence of the tetA gene and $35.29 \%$ had the tet $B$ gene. None of the investigated isolates harbored the tetC or tetD gene. The phenicol resistance gene catl was detected only in five isolates $(29.41 \%)$, and it was one of the three resistance genes tested for this class of antimicrobial agents. In contrast, among the seven fluoroquinolone resistance genes tested (qnrA, qnrB, qnrC, qnrD, qnrS, qepA, and aac(6')$I b-c r)$, only one $E$. coli strain (5.88\%) isolated from turkeys had $a a c\left(6^{\prime}\right)-I b-c r$. No differences were observed in the presence or absence of the selected resistance genes depending on the source of E. coli.

The results of biofilm assay are presented in Table 2. The results showed that all the $17 \mathrm{E}$. coli strains isolated from 


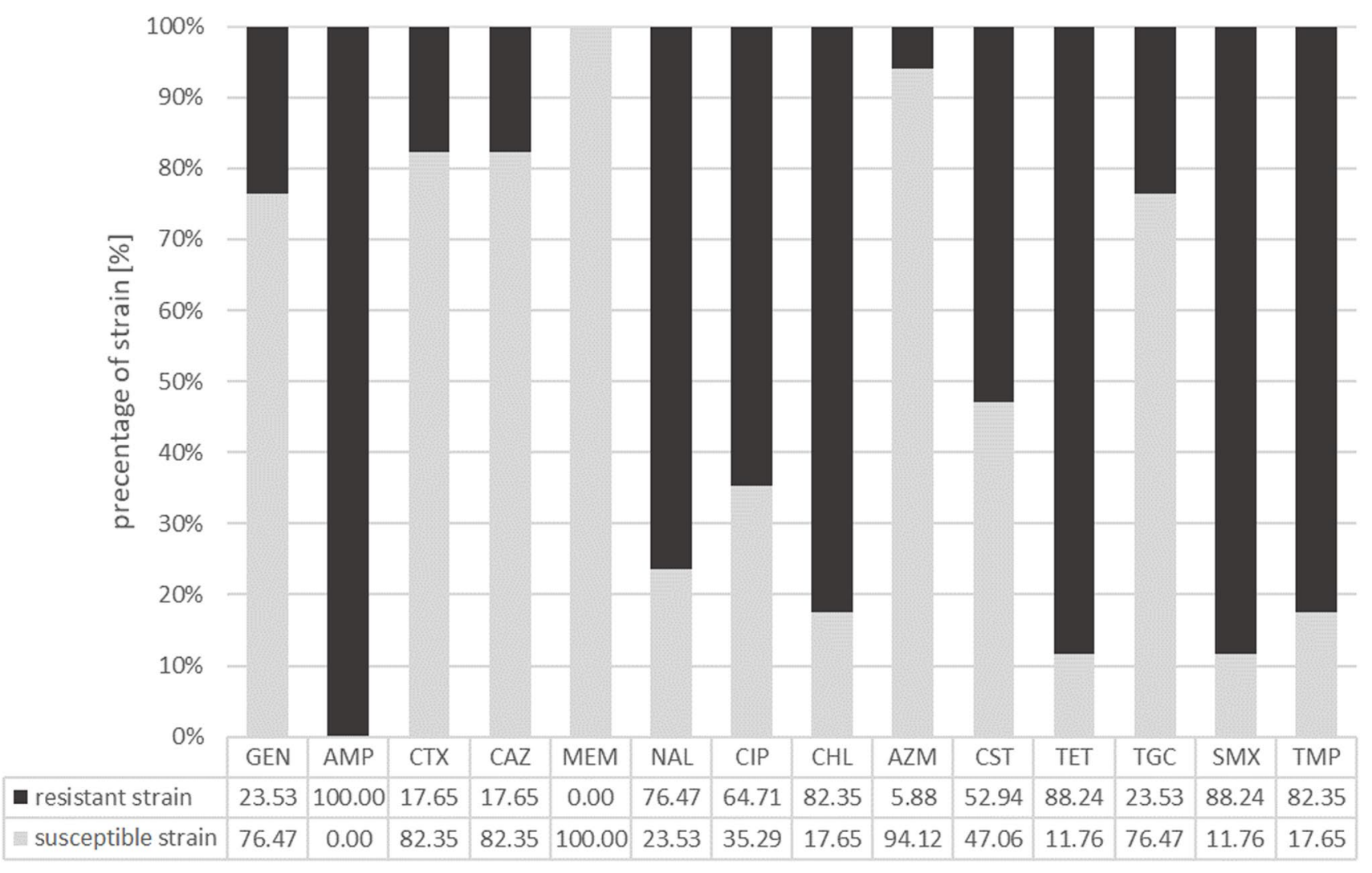

antimicrobial agent

Fig. 1 Antimicrobial susceptibility of the mcr-1 harboring E. coli strains $(n=17)$. GEN, gentamicin; AMP, ampicillin; CTX, cefotaxime; CAZ, ceftazidime; MEM, meropenem; NAL, nalidixic acid;

poultry origin produced biofilms, although at different levels of intensity. Under the assessed incubation conditions, most strains isolated from turkeys $(41.18 \%)$ produced biofilm weakly, while the remaining strains $(11.76 \%)$ were found to be moderate biofilm formers. In contrast, $23.53 \%$ of broiler isolates were medium biofilm producers and $17.65 \%$ isolated were weak biofilm producers. The only goose $E$. coli strain showed moderate biofilm production. It should be noted that none of the tested strains showed a strong biofilm formation.

\section{MLST}

On the basis of the combination of allelic profiles of the tested housekeeping genes, all $17 \mathrm{E}$. coli strains were assigned to the ST (Fig. 2). All loci showed four or more alleles among the 17 tested strains. The $a d k$ allele showed the least genetic variability (4 different alleles), whereas gyrB was the most genetically diverse (8 different alleles) among all investigated housekeeping genes.

The MLST analysis showed the occurrence of nine STs, among which the most frequent were ST93 and
CIP, ciprofloxacin; CHL, chloramphenicol; AZM, azithromycin; CST, colistin; TET, tetracycline; TGC, tigecycline; SMX, sulfamethoxazole; TMP, trimethoprim

ST117 (five and three isolates, respectively). The ST93 was observed in turkey isolates, while the ST117 in isolates obtained from broilers and from one goose. Moreover, the new ST was identified, which was related to the ST69 clonal complex. This complex includes the ST69 and ST408, which show the difference in $a d k$ allele (21 and 93, respectively). The new ST has an $a d k 83$ allele, which was different in 6 nucleotides in comparison to $a d k$ 21 allele, and in 7 nucleotides in comparison to adk 93 allele. The details of the differences between $a d k$ alleles are presented in Fig. 3.

The phylogenetic relationship showed that the strains of the same sequence types, such as ST93, ST117, ST156, and ST8979, despite their various origins, were assigned to the same clusters, and had the closest relationship with each other. Moreover, the closely related strains exhibited very similar profiles of carried resistance genes and the level of biofilm formation. All ST93 strains were isolated from turkeys and $60 \%$ (3/5) of them showed the same resistance gene profile and weak ability to form biofilms. All of the ST117 strains included isolates that harbored the $b l a_{\mathrm{TEM}}$, 
Table 2 Occurrence of resistance genes to antimicrobial agents, resistance profiles, biofilm formation, and sequence types (STs) in $m c r-1$-positive Escherichia coli strains $(\mathrm{n}=17)$

\begin{tabular}{|c|c|c|c|c|c|c|c|c|c|c|c|c|c|c|c|c|c|c|c|c|c|c|c|}
\hline \multirow[b]{2}{*}{ Origin } & \multirow[b]{2}{*}{ Strain } & \multicolumn{19}{|c|}{ Resistance genes } & \multirow[b]{2}{*}{ Multidrug resistance profile } & & \\
\hline & & 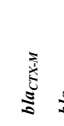 & 5 & 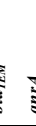 & 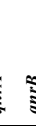 & 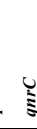 & 今 & $\underline{\Xi}$ & $\Xi$ & 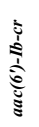 & $\bar{\Xi}$ & $\widehat{\Xi}$ & కิ & $\bar{J}$ & ปี & $\stackrel{\Xi}{\Xi}$ & ฐ & § & ฐ & $\widehat{\Xi}$ & & & \\
\hline \multirow{9}{*}{ Turkeys } & RF1/17 & & & & & & & & & & & & & & & & & & & & AMP CTX CAZ CIP TET TMP & + & 1011 \\
\hline & RF2/17 & & & & & & & & & & & & & & & & & & & & AMP CTX CAZ TET SMX TMP & + & 93 \\
\hline & RP1/17 & & & & & & & & & & & & & & & & & & & & AMP NAL CIP CHL TET SMX TMP & + & 93 \\
\hline & RP2/17 & & & & & & & & & & & & & & & & & & & & AMP NAL CIP CHL TET SMX TMP & + & 93 \\
\hline & RP3/17 & & & & & & & & & & & & & & & & & & & & AMP NAL CHL TET & + & 93 \\
\hline & AE02/18 & & & & & & & & & & & & & & & & & & & & AMP NAL CIP CST TET TGC SMX & ++ & 93 \\
\hline & AE21/18 & & & & & & & & & & & & & & & & & & & & GEN AMP CHL TGC SMX & + & 156 \\
\hline & AE178/20 & & & & & & & & & & & & & & & & & & & & AMP NAL CIP CHL AZM TET SMX TMP & ++ & 744 \\
\hline & AE342/20 & & & & & & & & & & & & & & & & & & & & GEN AMP CHL CST TET SMX TMP & + & new ST \\
\hline \multirow{7}{*}{ Broilers } & RW1/17 & & & & & & & & & & & & & & & & & & & & AMP NAL CHL CST SMX TMP & + & 8979 \\
\hline & RW2/17 & & & & & & & & & & & & & & & & & & & & GEN AMP NAL CIP CHL CST TET SMX TMP & ++ & 8979 \\
\hline & RW3/17 & & & & & & & & & & & & & & & & & & & & AMP CTX CAZ NAL CIP CHL TET SMX TMP & + & 10 \\
\hline & AE64/18 & & & & & & & & & & & & & & & & & & & & GEN AMP NAL CIP CHL CST TET TGC SMX TMP & ++ & 156 \\
\hline & AE71/18 & & & & & & & & & & & & & & & & & & & & AMP NAL CHL CST TET SMX TMP & + & 1137 \\
\hline & AE256/20 & & & & & & & & & & & & & & & & & & & & AMP NAL CIP CHL CST TET SMX TMP & ++ & 117 \\
\hline & AE257/20 & & & & & & & & & & & & & & & & & & & & AMP NAL CIP CHL CST TET SMX TMP & ++ & 117 \\
\hline Geese & AE05/18 & & & & & & & & & & & & & & & & & & & & AMP NAL CIP CHL CST TET TGC SMX TMP & ++ & 117 \\
\hline
\end{tabular}

White square - lack of resistance gene; black square - presence of resistance gene.

GEN, gentamicin; $A M P$, ampicillin; $C T X$, cefotaxime; $C A Z$, ceftazidime; $M E M$, meropenem; $N A L$, nalidixic acid; $C I P$, ciprofloxacin; $C H L$, chloramphenicol, $A Z M$, azithromycin; $C S T$, colistin; $T E T$, tetracycline; $T G C$, tigecycline; $S M X$, sulfamethoxazole; $T M P$, trimethoprim.

Biofilm formation: +++- strong biofilm former, ++- moderate biofilm former, +- weak biofilm former.

Fig. 2 Sequence types (STs) and MLST-based phylogenetic tree of $m c r$-1-positive E. coli isolates. The phylogenetic tree was constructed using the neighbor-joining method in MEGA 6.0 software

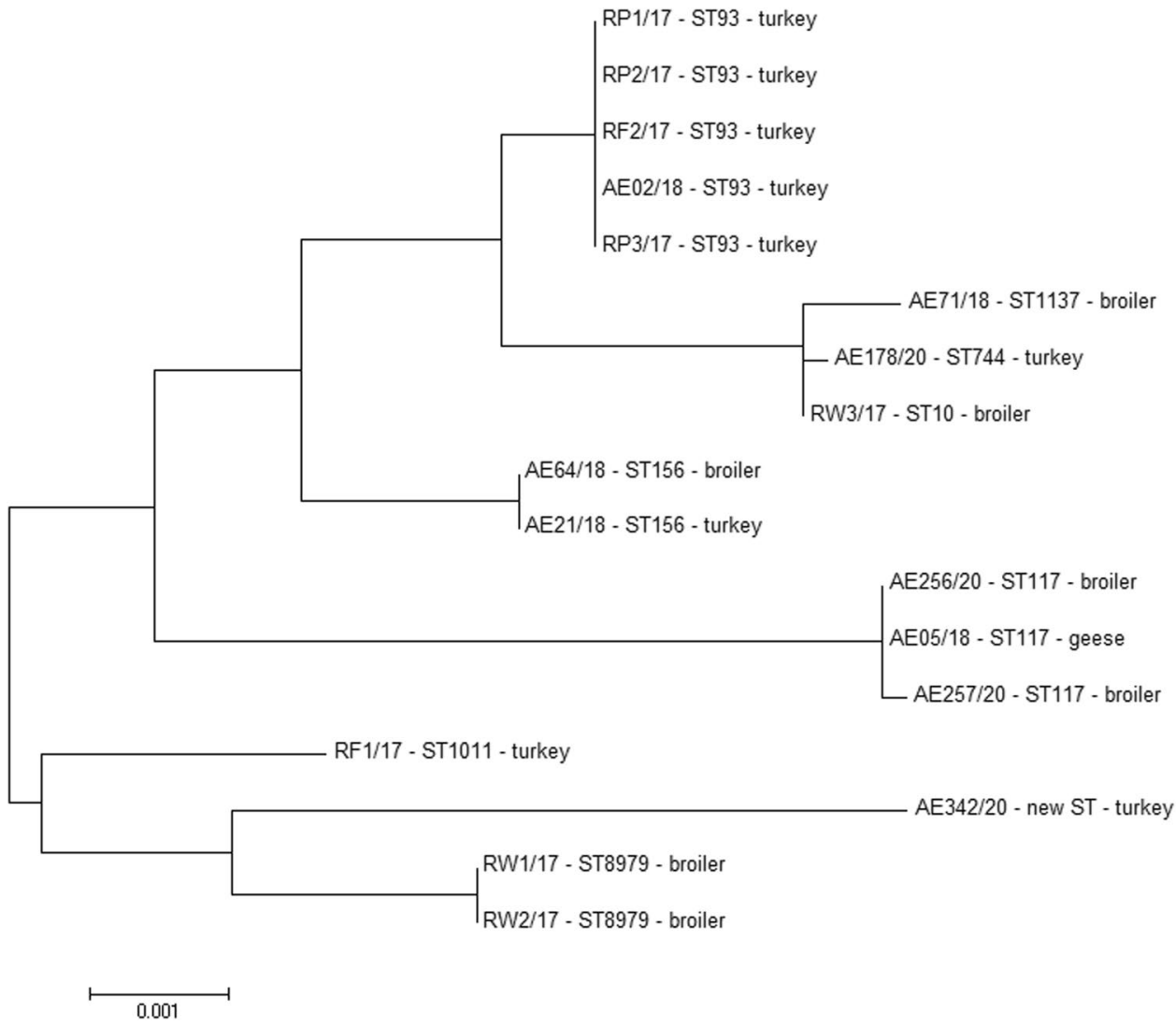




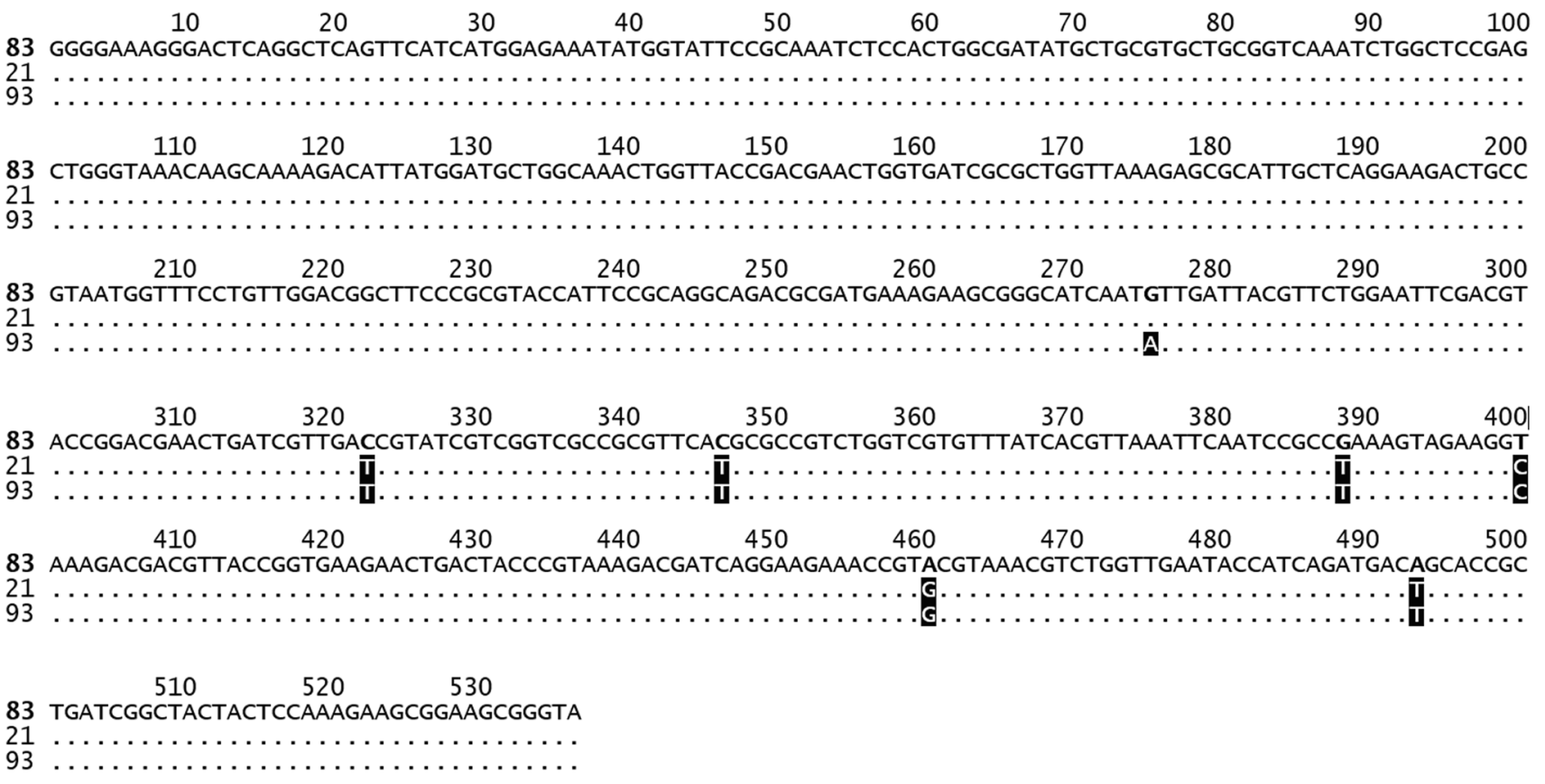

Fig. 3 The nucleotide differences in $a d k$ allele between the new ST and the ST69 clonal complex (ST69 and ST408)

cat1, tetB, sull, and sul2 genes, and they were moderate biofilm producers.

\section{Discussion}

Colistin resistance genes are widespread worldwide and have been found in Enterobacteriaceae from humans, food animals, and food, and among these resistance genes, the $\mathrm{mcr}-1$ gene is the most frequently isolated one [48, 49]. In Poland, the first $E$. coli strain with the $m c r-1$ gene was isolated in 2015 from a 50-year-old patient with a urinary tract infection. The man had contact with farm animals, which may confirm the involvement of animals in the transmission of colistin-resistant strains [50]. Zhang et al. [51] revealed the prevalence of colistin resistance genes ( $m c r-1, m c r-2$, and $m c r-3)$ in various species of poultry, with the highest prevalence of the mcr-1 gene, which was obtained from $71.7 \%$ of geese, $34.6 \%$ of ducks, and $31.8 \%$ of broilers. Moreover, a serious concern was the presence of all three $\mathrm{mcr}$ genes in three separate $E$. coli isolates from broilers.

Our study showed a low occurrence $(5.35 \%)$ of $\mathrm{mcr}$ 1 -harboring $E$. coli strains isolated from poultry. The other $m c r$ genes $(m c r 2-m c r 5)$ were not detected in the all analyzed strains; this finding is similar to the results obtained by other authors [52-54]. According to the research conducted in China by Zhao et al. [55], the percentage of $m c r-1$-positive $E$. coli strains isolated from poultry was $15.3 \%$, while it was only $0.34 \%$ in Japan [3]. Frequent use of antimicrobial agents in livestock production may lead to higher rate of resistant strain isolation, and commensal bacteria might serve as an indicator of antimicrobial usage for veterinary purposes [56]. A significantly higher percentage of colistinresistant E. coli strains in Poland was confirmed by studies conducted in 2017-2018, where the presence of the $\mathrm{mcr}-1$ gene occurring in the normal microbiota of chicken broilers, both treated and untreated with colistin sulfate, was tested. Isolates containing the $m c r-1$ gene were obtained in $11.27 \%$ of strains from untreated flocks and in $19.54 \%$ of isolates obtained from flocks treated with colistin [35]. In Europe, the prevalence of $E$. coli strains isolated from poultry and carrying the $m c r-1$ gene ranged from $1.5 \%$ in the Netherlands [28] to $13.95 \%$ in Portugal [54].

Irrgang et al. [57] showed that the prevalence of the $\mathrm{mcr}$ 1 gene depended on the type of poultry production. The highest prevalence of the $m c r-1$ gene was detected in turkeys (11.8\%), followed by broilers $(6.7 \%)$, and only three E. coli strains were $m c r-1$ positive in laying hens $(3 / 1,809$ investigated isolates). In our present study, the proportions remained similar, i.e., the $m c r-1$ gene was most frequently present in turkeys $(9 / 72 ; 12.50 \%)$, followed by broilers $(7 / 161 ; 4.35 \%)$. Clemente et al. [54] revealed that as many as $27 \%$ of turkey strains and only $2 \%$ of the investigated broiler strains harbored the $m c r-1$ gene.

In the present study, the highest resistance profile was observed for ampicillin (100\%), followed by sulfamethoxazole and tetracycline ( $88.24 \%$ for both), and trimethoprim and chloramphenicol ( $82.35 \%$ ex aequo); this finding is in accordance with other studies conducted in Brazil by Crecencio et al. [58] and in Portugal by Manageiro et al. [59]. 
Manageiro et al. revealed that a high percentage of $E$. coli strains isolated from broilers and turkeys were resistant to the following antimicrobial agents: ciprofloxacin $(90.6 \%$ and $79.5 \%$ ), nalidixic acid (88.6\% and $73.5 \%)$, ampicillin (75.7\% and $80 \%$ ), sulfamethoxazole (69.3\% and $71.9 \%)$, tetracycline (66.3\% and $85.9 \%$ ), trimethoprim (54.5\% and $49.7 \%$ ), and chloramphenicol (34.2\% and 52.4\%). Interestingly, multidrug resistance was observed in $81.3 \%$ of the isolates. Crecencio et al. [58] showed the highest resistance of retail chicken meat to beta-lactams (39.5\%), followed by sulfonamide combined with trimethoprim (36.9\%) and polymyxin (33.4\%).

In our present study, regarding the obtained MIC values for the selected antimicrobial agents, all the investigated mcr-1-positive E. coli strains showed MDR profile (resistance to at least three antimicrobial classes). Similar results were obtained by other authors from Brazil, China, Argentina, and Poland [29-31, 35, 60]. Monte et al. [29] showed that most of the $m c r-1$-positive $E$. coli isolates exhibited an MDR phenotype and carried genes conferring resistance to aminoglycosides, quinolones, sulfonamides, and tetracyclines. In the present study as well as in the study of Haenni et al. [61], the association between $m c r$ and other resistance elements such as beta-lactamases and the coexistence of the $m c r-1$ gene with sulfamethoxazole or tetracycline-resistance genes was observed. In our present study, the most frequently found resistance genes in the $m c r-1$-positive $E$. coli strains were as follows: $b l a_{\text {TEM }}$ (resistance to beta-lactams), tetA and tetB (resistance to tetracyclines), and sull, sul2, and sul3 genes (resistance to sulfonamides). These findings are in agreement with the results obtained by Zhao et al. [55] who showed that among $m c r-1$-positive $E$. coli strains, the $b l a_{\text {TEM }}$ gene was the most prevalent (100\%). $\beta$-lactamase encoding genes are usually localized on plasmids that facilitate their spread among Gram-negative bacilli via conjugation. Moreover, $\beta$-lactamase encoding plasmids often carry genes conferring resistance to other than $\beta$-lactam classes of antibiotics, limiting significantly the therapeutic options [62, $63]$. It should be emphasized here that $E$. coli is an opportunistic pathogen that is capable of causing illness in animals and humans; therefore, the isolation of MDR bacteria from food animals is a worldwide public health problem because of potential transfer of resistant pathogens to humans [56] and the possibility of transmission of antimicrobial resistance genes among gut bacteria.

Resistance to fluoroquinolones is either a chromosomally mediated mechanism causing mutation in the quinolone resistance-determining region (QRDR) within the subunits constituting topoisomerases II (GyrA and GyrB) and IV (ParC and ParE) or is encoded by plasmid-mediated quinolone resistance genes (PMQR) [qnrA, qnrB, qnrC, qnrD, $q n r S$, qepA, oqxAB, and aac(6')-Ib-cr], where the qepA and $o q x A B$ genes encode an efflux pump that decreases intracellular drug levels [23, 64, 65]. Moreover, decreased accumulation of fluoroquinolones because of impermeability of the membrane and/or overexpression of the efflux pump systems has also been established [66]. In the present study, $76.47 \%$ and $64.71 \%$ of the $m c r-1$-positive $E$. coli strains were resistant to nalidixic acid and ciprofloxacin, respectively, while the presence of the $a a c\left(6^{\prime}\right)-I b-c r$ gene was detected in only one strain. This difference between phenotypic resistance to quinolone antibiotics and the presence of the resistance genes is probably due to other resistance mechanisms, listed above, which were not investigated in the present study.

Biofilm formation by $E$. coli strains is one of their mechanisms of virulence and is important in the development of antibiotic resistance. In the present study, most of the investigated strains were weak biofilm producers $(58.82 \%)$, but a medium biofilm formation ability was observed in strains with multidrug resistance to 5,6 , or 7 classes of antimicrobial agents (41.18\%). Also Pavlickova et al. [56] showed the correlation between the prevalence of antibiotic resistance and biofilm formation ability. Moreover, $71 \%$ of $E$. coli strains isolated from chicken exhibited weak and medium biofilm production ability, which is in agreement with the results of our present study. In comparison, Crecencio et al. [58] showed that as many as $70.44 \%$ of $E$. coli strains isolated from retail chicken meat had moderate to strong biofilm formation ability. These discrepancies may depend on strain properties, culture conditions, environmental factors, and methodology [67]. Regarding the poultry species, medium biofilm-producing $E$. coli strains were most frequently isolated from broilers $(23.53 \%)$. This observation showed that on the one hand, multidrug resistance of these strains may enhance their virulence, especially in broiler isolates, and on the other hand, the general capacity of the $m c r$-1-positive E. coli strains to produce biofilms was at the medium and low level (no strong biofilm producers were observed in this study). Similar results were obtained by Barilli et al. [68], wherein E. coli strains isolated from retail meat products (including poultry) were weak biofilm producers. Although the tested in vitro strains did not show a strong biofilm production, it is worth noting that under appropriate in vivo conditions, with insufficient production hygiene, biofilm production may be more effective. Biofilm formation potential appears as an important virulence factor in ensuring the low penetration of antibiotics or disinfectants, and may lead to ineffective treatment.

In the present study, the MLST analysis revealed nine different $E$. coli STs. The most dominant sequence type was ST93 (29.41\%), followed by ST117 (17.65\%). Our study showed that eight obtained STs (ST93, ST1137, ST744, ST10, ST156, ST117, ST1011, and ST8979) have been isolated and previously identified among poultry in the USA, Europe, Asia, and Australia (data taken from EnteroBase). These STs were also noted in Poland, except for ST117 and 
ST1011, which were isolated for the first time from poultry source in our study. The newly identified ST was the most related to the ST69 clonal complex, which includes the ST69, widely distributed in the environment, and the ST408 which has been isolated from bovine in the USA.

It is worth noting that in the present study, two strains isolated from broilers were described as ST8979; according to the EnteroBase, this ST has been isolated only twice from the environment in the USA. The ST1137 was deposited in the EnteroBase in 12 cases, including three strains each isolated from poultry in the USA, France, and Kenya. Additionally, three of STs (ST10, ST93, and ST744), obtained in the present study, were detected in E. coli from samples of raw poultry meat and liver, which came from Poland and were retailed in the Czech Republic. This investigation suggests that it poses a significant threat to public health [69].

Zhao et al. [38, 55] showed that among the mcr-1-positive $E$. coli strains isolated from poultry farms in China, the dominant ST was ST93 (18.62\%); this finding is in agreement with the results obtained in the present study. The ST93, ST117, and ST156 were also described in $E$. coli strains obtained from chicken broilers in Egypt [70]. In Switzerland, Zurfluh et al. [71] characterized the ST156 in an $m c r-1$-positive $E$. coli strain isolated from chicken meat, while Hassen et al. [72] revealed the presence of ST117 in a beta-lactamase-producing $m c r-1$-encoding $E$. coli strain isolated from chicken meat samples in Tunisia. The other STs, namely ST10 and ST117 were found in E. coli isolated from broilers at slaughter [73] and broiler breeders [74], respectively. In Poland, Zając et al. [34] described 49 STs among the $m c r$-1-positive $E$. coli strains isolated from chicken and turkeys, among which the most common types were ST354 and ST359, which were not observed in our present study. The common STs for both classes of strains, published by Zając et al. [34] and in the present study, were ST10, ST93, ST117, and ST1011. In addition, in the present study, 60.0\% (3/5) of ST93 isolates carried the bla ${ }_{\mathrm{TEM}}$, tetA, sull, sul2, and sul 3 genes, and they showed $100 \%$ similarity on the MLST phylogenetic tree; this finding may indicate clonal types of these strains.

\section{Conclusion}

In summary, the conducted research confirmed that poultry can be considered as an important reservoir of MDR E. coli isolates. A wide range of phenotypic resistance to both antibiotics used in veterinary and human medicine was identified and resistance to colistin, tetracycline, quinolones, and $\beta$-lactams was observed among the analyzed strains. Additionally, strains with multidrug resistance to 5,6 , or 7 classes of antimicrobial agents were medium biofilm producers. The co-resistance of plasmid-mediated colistin resistance encoded by $m c r-1$ gene and tet ( $A$ and $B$ ) or $b l a_{\text {TEM }}$ genes was $88.24 \%$, equally. Furthermore, our findings suggest the diversity in resistance determinants, which could be responsible for the high resistance profiles found in this study. This may pose a threat to public health due to the existing risk of spread of resistance genes among bacterial strains, including their potential ability to transfer antimicrobial resistance to humans.

Due to the fact that Poland is a significant poultry producer in Europe, research on this aspect should be widely conducted in Poland and constantly improved. It is essential to monitor colistin-resistant $E$. coli strains for understanding the prevalence of colistin resistance genes in both human and veterinary medicine, including poultry production.

Author contribution Conception and design the study: K.Ć., A.WB., A.W.; Microbiology and molecular testing: K.Ć., M.Ka., M.S.; Data analysis: K.Ć., A.WB., A.W.; Draft paper: K.Ć., A.WB., M.Ka., M.S., A.W.; Review manuscript: K.Ć., A.WB., M.Ka., M.S., A.R.R., R.S.H., A.W.; Approve final manuscript: K.Ć., A.WB., M.Ka., M.S., C.L., A.R.R., R.S.H., M.Ku., M.CW., A.W.; Submission: A.WB.

Funding The research is financed under the Leading Research Groups support project from the subsidy increased for the period 2020-2025 in the amount of $2 \%$ of the subsidy referred to Art. 387 (3) of the Law of 20 July 2018 on Higher Education and Science, obtained in 2019.

\section{Declarations}

Ethics approval Not applicable.

Competing interests The authors declare no competing interests.

Open Access This article is licensed under a Creative Commons Attribution 4.0 International License, which permits use, sharing, adaptation, distribution and reproduction in any medium or format, as long as you give appropriate credit to the original author(s) and the source, provide a link to the Creative Commons licence, and indicate if changes were made. The images or other third party material in this article are included in the article's Creative Commons licence, unless indicated otherwise in a credit line to the material. If material is not included in the article's Creative Commons licence and your intended use is not permitted by statutory regulation or exceeds the permitted use, you will need to obtain permission directly from the copyright holder. To view a copy of this licence, visit http://creativecommons.org/licenses/by/4.0/.

\section{References}

1. World Health Organization (WHO) (2014) Antimicrobial resistance: global report on surveillance. WHO, Geneva

2. Apostolakos I, Piccirillo A (2018) A review on the current situation and challenges of colistin resistance in poultry production. Avian Pathol 47:546-558. https://doi.org/10.1080/03079457. 2018.1524573

3. Kawanishi M, Abo H, Ozawa M, Uchiyama M, Shirakawa T, Suzuki S, Shima A, Yamashita A, Sekizuka T, Kato K, Kuroda 
M, Koike R, Kijima M (2016) Prevalence of colistin resistance gene mcr-1 and absence of mcr-2 in Escherichia coli isolated from healthy food-producing animals in Japan. Antimicrob Agents Chemother 61:e02057-e2116. https://doi.org/10.1128/AAC. 02057-16

4. Umpiérrez A, Bado I, Oliver M, Acquistapace S, Etcheverría A, Padola NL, Vignoli R, Zunino P (2017) Zoonotic potential and antibiotic resistance of Escherichia coli in neonatal calves in Uruguay. Microbes Environ 32:275-282. https://doi.org/10.1264/ jsme2.ME17046

5. Yang $\mathrm{H}$, Chen $\mathrm{S}$, White DG, Zhao S, McDermott P, Walker R, Meng J (2004) Characterization of multiple-antimicrobial-resistant Escherichia coli isolates from diseased chickens and swine in China. J Clin Microbiol 42:3483-3489. https://doi.org/10.1128/ JCM.42.8.3483-3489.2004

6. Forde BM, Zowawi HM, Harris PNA, Roberts L, Ibrahim E, Shaikh N, Deshmukh A, Sid MA, Al Ahmed M, Cottrell K, Trembizki E, Sundac L, Yu HH, Li J, Schembri MA, Whiley DM, Paterson DL, Beatson S A (2018) Discovery of mcr-1-Mediated Colistin Resistance in a Highly Virulent Escherichia coli Lineage. mSphere 3:e00486-18. https://doi.org/10.1128/mSphere.00486-18

7. Kim S, Woo JH, Kim N, Kim MH, Kim SY, Son JH, Moon DC, Lim SK, Shin M, Lee JC (2019) Characterization Of chromosome-mediated colistin resistance in Escherichia coli isolates from livestock in Korea. Infect Drug Resist 12:3291-3299. https://doi. org/10.2147/IDR.S225383

8. Liu YY, Wang Y, Walsh TR, Yi LX, Zhang R, Spencer J, Doi Y, Tian G, Dong B, Huang X, Yu LF, Gu D, Ren H, Chen X, Lv L, He D, Zhou H, Liang Z, Liu JH, Shen J (2016) Emergence of plasmid-mediated colistin resistance mechanism MCR-1 in animals and human beings in China: a microbiological and molecular biological study. Lancet Infect Dis 16:161-8. https://doi.org/10. 1016/S1473-3099(15)00424-7

9. Hernández M, Iglesias MR, Rodríguez-Lázaro D, Gallardo A, Quijada N, Miguela-Villoldo P, Campos MJ, Píriz S, LópezOrozco G, de Frutos C, Sáez JL, Ugarte-Ruiz M, Domínguez L, Quesada A (2017) Co-occurrence of colistin-resistance genes mcr-1 and mcr-3 among multidrug-resistant Escherichia coli isolated from cattle, Spain, September 2015. Euro Surveill 22:30586. https://doi.org/10.2807/1560-7917.ES.2017.22.31.30586

10. Borowiak M, Fischer J, Hammerl JA, Hendriksen RS, Szabo I, Malorny B (2017) Identification of a novel transposon-associated phosphoethanolamine transferase gene, mcr-5, conferring colistin resistance in d-tartrate fermenting Salmonella enterica subsp. enterica serovar Paratyphi B. J Antimicrob Chemother 72:33173324. https://doi.org/10.1093/jac/dkx327

11. Borowiak M, Baumann B, Fischer J, Thomas K, Deneke C, Hammerl JA, Szabo I, Malorny B (2020) Development of a novel mcr- 6 to mcr- 9 multiplex PCR and assessment of mcr- 1 to mcr- 9 occurrence in colistin-resistant Salmonella enterica isolates from environment, feed, animals and food (2011-2018) in Germany. Front Microbiol 11:80. https://doi.org/10.3389/fmicb.2020.00080

12. Carattoli A, Villa L, Feudi C, Curcio L, Orsini S, Luppi A, Pezzotti G, Magistrali CF (2017) Novel plasmid-mediated colistin resistance mcr-4 gene in Salmonella and Escherichia coli, Italy 2013, Spain and Belgium, 2015 to 2016. Euro Surveill 22:30589. https://doi.org/10.2807/1560-7917.ES.2017.22.31.30589

13. El Garch F, Sauget M, Hocquet D, LeChaudee D, Woehrle F, Bertrand X (2017) mcr-1 is borne by highly diverse Escherichia coli isolates since 2004 in food-producing animals in Europe. Clin Microbiol Infect 23:51.e1-51.e4. https://doi.org/10.1016/j. cmi.2016.08.033

14. Wang X, Wang Y, Zhou Y, Li J, Yin W, Wang S, Zhang S, Shen J, Shen Z, Wang Y (2018) Emergence of a novel mobile colistin resistance gene, mcr-8, in NDM-producing Klebsiella pneumoniae. Emerg Microbes Infect 7:122. https://doi.org/10. 1038/s41426-018-0124-Z

15. Li Y, Dai X, Zeng J, Gao Y, Zhang Z, Zhang L (2020) Characterization of the global distribution and diversified plasmid reservoirs of the colistin resistance gene mcr-9. Sci Rep 10:8113. https://doi. org/10.1038/s41598-020-65106-w

16. Kieffer N, Nordmann P, Poirel L (2017) Moraxella species as potential sources of MCR-like polymyxin resistance determinants. Antimicrob Agents Chemother 61:e00129-e217. https://doi.org/ 10.1128/AAC.00129-17

17. Ling Z, Yin W, Li H, Zhang Q, Wang X, Wang Z, Ke Y, Wang Y, Shen J (2017) Chromosome-mediated mcr-3 variants in Aeromonas veronii from chicken meat. Antimicrob Agents Chemother 61:e01272-e1317. https://doi.org/10.1128/AAC.01272-17

18. Carroll LM, Gaballa A, Guldimann C, Sullivan G, Henderson LO, Wiedmann M (2019) Identification of novel mobilized colistin resistance gene mcr-9 in a multidrug-resistant, colistin-susceptible Salmonella enterica serotype Typhimurium isolate. mBio 10:e00853-19. https://doi.org/10.1128/mBio.00853-19

19. Wang C, Feng Y, Liu L, Wei L, Kang M, Zong Z (2020) Identification of novel mobile colistin resistance gene mcr-10. Emerg Microbes Infect 9:508-516. https://doi.org/10.1080/22221751. 2020.1732231

20. Li R, Xie M, Lv J, Wai-Chi Chan E, Chen S (2017) Complete genetic analysis of plasmids carrying mcr-1 and other resistance genes in an Escherichia coli isolate of animal origin. J Antimicrob Chemother 72:696-699. https://doi.org/10.1093/jac/dkw509

21. Liu J, Liu P, Feng F, Zhang J, Li F, Wang M, Sun Y (2020) Evaluation of potential ARG packaging by two environmental T7-like phage during phage-host interaction. Viruses 12:1060. https://doi. org/10.3390/v12101060

22. Ye H, Li Y, Li Z, Gao R, Zhang H, Wen R, Gao GF, Hu Q, Feng $Y$ (2016) Diversified mcr-1-harbouring plasmid reservoirs confer resistance to colistin in human gut microbiota. mBio 7:e00177. https://doi.org/10.1128/mBio.00177-16

23. Nordmann P, Poirel L (2005) Emergence of plasmid-mediated resistance to quinolones in Enterobacteriaceae. J Antimicrob Chemother 56:463-469. https://doi.org/10.1093/jac/dki245

24. Poirel L, Jayol A, Nordmann P (2017) Polymyxins: antibacterial activity, susceptibility testing, and resistance mechanisms encoded by plasmids or chromosomes. Clin Microbiol Rev 30:557-596. https://doi.org/10.1128/CMR.00064-16

25. Villegas NA, Baronetti J, Albesa I, Polifroni R, Parma A, Etcheverría A, Becerra M, Padola N, Paraje M (2013) Relevance of biofilms in the pathogenesis of Shiga-toxin-producing Escherichia coli infection. ScientificWorldJournal 2013:607258. https://doi. org/10.1155/2013/607258

26. Cepas V, López Y, Muñoz E, Rolo D, Ardanuy C, Martí S, Xercavins M, Horcajada JP, Bosch J, Soto SM (2019) Relationship between biofilm formation and antimicrobial resistance in Gramnegative bacteria. Microb Drug Resist 25:72-79. https://doi.org/ 10.1089/mdr.2018.0027

27. Lora-Tamayo J, Murillo O, Ariza J (2019) Clinical use of colistin in biofilm-associated infections. Adv Exp Med Biol 1145:181195. https://doi.org/10.1007/978-3-030-16373-0_13

28. Kluytmans-van den Bergh MF, Huizinga P, Bonten MJ, Bos M, De Bruyne K, Friedrich AW, Rossen JW, Savelkoul PH, Kluytmans JA (2016) Presence of mcr-1-positive Enterobacteriaceae in retail chicken meat but not in humans in the Netherlands since 2009. Euro Surveill 21:30149. https://doi.org/10.2807/1560-7917. ES.2016.21.9.30149

29. Monte DF, Mem A, Fernandes MR, Cerdeira L, Esposito F, Galvão JA, Franco BDGM, Lincopan N, Landgraf M (2017) Chicken meat as a reservoir of colistin-resistant Escherichia coli strains carrying mcr-1 genes in South America. Antimicrob Agents 
Chemother 61:e02718-e2816. https://doi.org/10.1128/AAC. 02718-16

30. Dominguez JE, Redondo LM, Figueroa Espinosa RA, Cejas D, Gutkind GO, Chacana PA, Di Conza JA, Fernández Miyakawa ME (2018) Simultaneous carriage of mcr-1 and other antimicrobial resistance determinants in Escherichia coli from poultry. Front Microbiol 9:1679. https://doi.org/10.3389/fmicb.2018. 01679

31. Song Y, Yu L, Zhang Y, Dai Y, Wang P, Feng C, Liu M, Sun S, Xie Z, Wang F (2020) Prevalence and characteristics of multidrug-resistant mcr-1-positive Escherichia coli isolates from broiler chickens in Tai'an, China. Poult Sci 99:1117-1123. https://doi. org/10.1016/j.psj.2019.10.044

32. Wasyl D, Hoszowski A, Zając M, Szulowski K (2013) Antimicrobial resistance in commensal Escherichia coli isolated from animals at slaughter. Front Microbiol 4:221. https://doi.org/10. 3389/fmicb.2013.00221

33. Wasyl D, Zając M, Lalak A, Skarżyńska M, Samcik I, Kwit R, Jabłoński A, Bocian Ł, Woźniakowski G, Hoszowski A, Szulowski K (2018) Antimicrobial resistance in Escherichia coli isolated from wild animals in Poland. Microb Drug Resist 24:807-815. https://doi.org/10.1089/mdr.2017.0148

34. Zając M, Sztromwasser P, Bortolaia V, Leekitcharoenphon $P$, Cavaco LM, Ziẹtek-Barszcz A, Hendriksen RS, Wasyl D (2019) Occurrence and characterization of mcr-1-positive Escherichia coli isolated from food-producing animals in Poland, 2011-2016. Front Microbiol 10:1753. https://doi.org/10.3389/fmicb.2019. 01753

35. Majewski M, Łukomska A, Wilczyński J, Wystalska D, Racewicz P, Nowacka-Woszuk J, Pszczola M, Anusz K (2020) Colistin resistance of non-pathogenic strains of Escherichia coli occurring as natural intestinal flora in broiler chickens treated and not treated with colistin sulphate. J Vet Res 64:399-405. https://doi.org/10. 2478/jvetres-2020-0060

36. Desjardins P, Conklin D (2010) NanoDrop microvolume quantitation of nucleic acids. J Vis Exp 22:2565. https://doi.org/10.3791/ 2565

37. Rebelo AR, Bortolaia V, Kjeldgaard JS, Pedersen SK, Leekitcharoenphon P, Hansen IM, Guerra B, Malorny B, Borowiak M, Hammerl JA, Battisti A, Franco A, Alba P, Perrin-Guyomard A, Granier SA, De Frutos EC, Malhotra-Kumar S, Villa L, Carattoli A, Hendriksen RS (2018) Multiplex PCR for detection of plasmid-mediated colistin resistance determinants, mcr-1, mcr-2, mcr-3, mcr-4 and mcr-5 for surveillance purposes. Euro Surveill 23:17-00672. https://doi.org/10.2807/1560-7917.ES.2018.23.6. 17-00672

38. EUCAST (2020) The European Committee on Antimicrobial Susceptibility Testing. Breakpoint tables for interpretation of MICs and zone diameters. Version 10.0

39. CLSI (2019) Subcommittee on Antimicrobial Susceptibility Testing. M100 Performance Standards for Antimicrobial Susceptibility Testing. 29th Edition

40. Türkyılmaz S, Hazimoglu S, Bozdogan B (2009) Antimicrobial susceptibility and resistance genes in Salmonella enterica serovar enteritidis isolated from Turkeys. Israel J Vet Med 64:72-77

41. Ćwiek K, Korzekwa K, Tabiś A, Bania J, Bugla-Płoskońska G, Wieliczko A (2020) Antimicrobial resistance and biofilm formation capacity of Salmonella enterica Serovar Enteritidis strains isolated from poultry and humans in Poland. Pathogens 9:643. https://doi.org/10.3390/pathogens9080643

42. Pratt LA, Kolter R (1998) Genetic analysis of Escherichia coli biofilm formation: roles of flagella, motility, chemotaxis and type I pili. Mol Microbiol 30:285-293. https://doi.org/10.1046/j.13652958.1998.01061.x
43. Sun Y, Hu X, Guo D, Shi C, Zhang C, Peng X, Yang H, Xia $X$ (2019) Disinfectant resistance profiles and biofilm formation capacity of Escherichia coli isolated from retail chicken. Microb Drug Resist 25:703-711. https://doi.org/10.1089/mdr.2018.0175

44. Wirth T, Falush D, Lan R, Colles F, Mensa P, Wieler LH, Karch H, Reeves PR, Maiden MC, Ochman H, Achtman M (2006) Sex and virulence in Escherichia coli: an evolutionary perspective. Mol Microbiol 60:1136-1151. https://doi.org/10.1111/j.13652958.2006.05172.x

45. Kimura M (1980) A simple method for estimating evolutionary rates of base substitutions through comparative studies of nucleotide sequences. J Mol Evol 16:111-120. https://doi.org/10.1007/ BF01731581

46. Hall TA (1999) BioEdit: a user-friendly biological sequence alignment editor and analysis program for Windows 95/98/NT. Nucleic Acids Symp Ser 41:95-98

47. Tamura K, Stecher G, Peterson D, Filipski A, Kumar S (2013) MEGA6: molecular evolutionary genetics analysis version 6.0. Mol Biol Evol 30:2725-2729. https://doi.org/10.1093/molbev/ mst197

48. Luo Q, Wang Y, Xiao Y (2020) Prevalence and transmission of mobilized colistin resistance (mcr) gene in bacteria common to animals and humans. Biosafety and Health 2:71-78. https://doi. org/10.1016/j.bsheal.2020.05.001

49. Savin M, Bierbaum G, Blau K, Parcina M, Sib E, Smalla K, Schmithausen R, Heinemann C, Hammerl JA, Kreyenschmidt J (2020) Colistin-resistant Enterobacteriaceae isolated from process waters and wastewater from German poultry and pig slaughterhouses. Front Microbiol 11:575391. https://doi.org/10.3389/ fmicb.2020.575391

50. Izdebski R, Baraniak A, Bojarska K, Urbanowicz P, Fiett J, Pomorska-Wesołowska M, Hryniewicz W, Gniadkowski M, Żabicka D (2016) Mobile MCR-1-associated resistance to colistin in Poland. J Antimicrob Chemother 71:2331-2333. https://doi. org/10.1093/jac/dkw261

51. Zhang J, Chen L, Wang J, Yassin AK, Butaye P, Kelly P, Gong J, Guo W, Li J, Li M, Yang F, Feng Z, Jiang P, Song C, Wang Y, You J, Yang Y, Price S, Qi K, Kang Y, Wang C (2018) Molecular detection of colistin resistance genes (mcr-1, mcr-2 and mcr-3) in nasal/oropharyngeal and anal/cloacal swabs from pigs and poultry. Sci Rep 8:3705. https://doi.org/10.1038/s41598-018-22084-4

52. Lima Barbieri N, Nielsen DW, Wannemuehler Y, Cavender T, Hussein A, Yan SG, Nolan LK, Logue CM (2017) mcr-1 identified in Avian Pathogenic Escherichia coli (APEC). PLoS One 12(3):e0172997. https://doi.org/10.1371/journal.pone.0172997

53. Yang YQ, Li YX, Song T, Yang YX, Jiang W, Zhang AY, Guo XY, Liu BH, Wang YX, Lei CW, Xiang R, Wang HN (2017) Colistin resistance gene mcr-1 and its variant in Escherichia coli isolates from chickens in China. Antimicrob Agents Chemother 61(5):e01204-e1216. https://doi.org/10.1128/AAC.01204-16

54. Clemente L, Manageiro V, Correia I, Amaro A, Albuquerque T, Themudo P, Ferreira E, Caniça M (2019) Revealing mcr-1-positive ESBL-producing Escherichia coli strains among Enterobacteriaceae from food-producing animals (bovine, swine and poultry) and meat (bovine and swine), Portugal, 2010-2015. Int J Food Microbiol 296:37-42. https://doi.org/10.1016/j.ijfoodmicro.2019. 02.006

55. Zhao X, Liu Z, Zhang Y, Yuan X, Hu M, Liu Y (2020) Prevalence and molecular characteristics of avian-origin mcr-1-harboring Escherichia coli in Shandong Province. China Front Microbiol 11:255. https://doi.org/10.3389/fmicb.2020.00255

56. Pavlickova S, Klancnik A, Dolezalova M, Mozina SS, Holko I (2017) Antibiotic resistance, virulence factors and biofilm formation ability in Escherichia coli strains isolated from chicken 
meat and wildlife in the Czech Republic. J Environ Sci Health B 52:570-576. https://doi.org/10.1080/03601234.2017.1318637

57. Irrgang A, Roschanski N, Tenhagen BA, Grobbel M, Skladnikiewicz-Ziemer T, Thomas K, Roesler U, Käsbohrer A (2016) Prevalence of mcr-1 in E. coli from livestock and food in Germany, 2010-2015. PloS One 11:e0159863. https://doi.org/10.1371/journ al.pone. 0159863

58. Crecencio RB, Brisola MC, Bitner D, Frigo A, Rampazzo L, Borges KA, Furian TQ, Salle CTP, Moraes HLS, Faria GA, Da Silva AS, Stefani LM (2020) Antimicrobial susceptibility, biofilm formation and genetic profiles of Escherichia coli isolated from retail chicken meat. Infect Genet Evol 84:104355. https://doi.org/ 10.1016/j.meegid.2020.104355

59. Manageiro V, Clemente L, Graça R, Correia I, Albuquerque T, Ferreira E, Caniça M (2017) New insights into resistance to colistin and third-generation cephalosporins of Escherichia coli in poultry, Portugal: Novel bla ${ }_{\mathrm{CTX}-\mathrm{M}-166}$ and bla $\mathrm{ESAC}_{\mathrm{E}}$ genes. Int $\mathrm{J}$ Food Microbiol 263:67-73. https://doi.org/10.1016/j.ijfoodmicro. 2017.10.007

60. Zhuge X, Ji Y, Tang F, Sun Y, Jiang M, Hu W, Wu Y, Xue F, Ren J, Zhu W, Dai J (2019) Population structure and antimicrobial resistance traits of avian-origin mcr-1-positive Escherichia coli in Eastern China, 2015 to 2017. Transbound Emerg Dis 66:1920 1929. https://doi.org/10.1111/tbed.13222

61. Haenni M, Poirel L, Kieffer N, Châtre P, Saras E, Métayer V, Dumoulin R, Nordmann P, Madec JY (2016) Co-occurrence of extended spectrum $\beta$ lactamase and MCR-1 encoding genes on plasmids. Lancet Infect Dis 16:281-282. https://doi.org/10.1016/ S1473-3099(16)00007-4

62. Wu C, Wang Y, Shi X, Wang S, Ren H, Shen Z, Wang Y, Lin J, Wang S (2018) Rapid rise of the ESBL and mor-1 genes in Escherichia coli of chicken origin in China, 2008-2014. Emerg Microbes Infect 7:30. https://doi.org/10.1038/s41426-018-0033-1

63. Shafiq M, Huang J, Shah JM, Ali I, Rahman SU, Wang L (2021) Characterization and resistant determinants linked to mobile elements of ESBL-producing and mcr-1-positive Escherichia coli recovered from the chicken origin. Microb Pathog 150:104722. https://doi.org/10.1016/j.micpath.2020.104722

64. Hansen LH, Jensen LB, Sørensen HI, Sørensen SJ (2007) Substrate specificity of the OqxAB multidrug resistance pump in Escherichia coli and selected enteric bacteria. J Antimicrob Chemother 60:145-147. https://doi.org/10.1093/jac/dkm167

65. Poirel L, Madec J-Y, Lupo A, Schink A-K, Kieffer N, Nordmann P, Schwarz S (2018) Antimicrobial resistance in Escherichia coli. Microbiol Spectrum 6(4):ARBA-0026-2017. https://doi.org/10. 1128/microbiolspec.ARBA-0026-2017

66. Ruiz J (2003) Mechanisms of resistance to quinolones: target alterations, decreased accumulation and DNA gyrase protection. J Antimicrob Chemother 51:1109-1117. https://doi.org/10.1093/ $\mathrm{jac} / \mathrm{dkg} 222$
67. Naves P, del Prado G, Huelves L, Gracia M, Ruiz V, Blanco J, Rodríguez-Cerrato V, Ponte MC, Soriano F (2008) Measurement of biofilm formation by clinical isolates of Escherichia coli is method-dependent. J Appl Microbiol 105:585-590. https://doi. org/10.1111/j.1365-2672.2008.03791.x

68. Barilli E, Vismarra A, Frascolla V, Rega M, Bacci C (2020) Escherichia coli strains isolated from retail meat products: evaluation of biofilm formation ability, antibiotic resistance, and phylogenetic group analysis. J Food Prot 14:233-240. https://doi.org/ 10.4315/0362-028X.JFP-19-330

69. Gelbíčová T, Baráková A, Florianová M, Jamborová I, Zelendová M, Pospíšilová L, Koláčková I, Karpíšková R (2019) Dissemination and comparison of genetic determinants of mcr-mediated colistin resistance in Enterobacteriaceae via retailed raw meat products. Front Microbiol 10:2824. https://doi.org/10.3389/fmicb. 2019.02824

70. Hussein AH, Ghanem IA, Eid AA, Ali MA, Sherwood JS, Li G, Nolan LK, Logue CM (2013) Molecular and phenotypic characterization of Escherichia coli isolated from broiler chicken flocks in Egypt. Avian Dis 57:602-611. https://doi.org/10.1637/ 10503-012513-Reg.1

71. Zurfluh K, Nüesch-Inderbinen M, Klumpp J, Poirel L, Nordmann P, Stephan R (2017) Key features of $m c r$ - 1 -bearing plasmids from Escherichia coli isolated from humans and food. Antimicrob Resist Infect Control 6:91. https://doi.org/10.1186/ s13756-017-0250-8

72. Hassen B, Abbassi MS, Ruiz-Ripa L, Mama OM, Hassen A, Torres C, Hammami S (2020) High prevalence of mcr-1 encoding colistin resistance and first identification of bla CTX-M-55 $_{\text {in ESBL/ }}$ CMY-2-producing Escherichia coli isolated from chicken faeces and retail meat in Tunisia. Int J Food Microbiol 318:108478. https://doi.org/10.1016/j.ijfoodmicro.2019.108478

73. Castellanos LR, Donado-Godoy P, León M, Clavijo V, Arevalo A, Bernal JF, Timmerman AJ, Mevius DJ, Wagenaar JA, Hordijk J (2017) High heterogeneity of Escherichia coli sequence types harbouring ESBL/AmpC genes on IncI1 plasmids in the Colombian poultry chain. PLoS One 12:e0170777. https://doi.org/10. 1371/journal.pone.0170777

74. Landman WJ, Buter GJ, Dijkman R, van Eck JH (2014) Molecular typing of avian pathogenic Escherichia coli colonies originating from outbreaks of E. coli peritonitis syndrome in chicken flocks. Avian Pathol 43:345-356. https://doi.org/10.1080/03079457. 2014.935291

Publisher's note Springer Nature remains neutral with regard to jurisdictional claims in published maps and institutional affiliations. 